\title{
ДІАБЕТИЧНА СТОПА ТА ОСОБЛИВОСТІ ПСИХОЕМОЦІЙНИХ І КОГНІТИВНИХ ПОРУШЕНЬ У ПАЦІЄНТІВ ІЗ ЦУКРОВИМ ДІАБЕТОМ 2 ТИПУ
}

\section{Діабетична стопа та особливості психоемоційних і когнітивних порушень у пацієнтів із цукровим діабетом 2 типу}

\section{л. В. Наумова, Л. П. Мазур, В. М. Кульчінська}

Тернопільський національний медичний університет імені І. Я. Горбачевського МОЗ України

Резюме. Цукровий діабет (ЦД) є однією з найпоширеніших та найбільш ускладнених ендокринних патологій. У виникненні його на даний час роль психологічного параметра (стресу) є доведеною.

Мета дослідження - виявити психоемоційні та когнітивні порушення у пацієнтів із цукровим діабетом 2 типу, ускладненого діабетичною стопою.

Матеріали і методи. Ми обстежили 59 пацієнтів 3 ЦД 2 типу віком 45-70 років з тривалістю захворювання 4-22 роки. Когнітивну сореру було обстежено за допомогою шкали Mini Mental State Examination.

Результати. У роботі представлено результати аналізу психоемоційних та когнітивних порушень у пацієнтів із цукровим діабетом 2 типу, ускладненим діабетичною стопою.

Висновки. Автори відзначають прямо пропорційну залежність між клінічною фрормою діабетичної стопи та ступенем вираження когнітивних порушень.

Ключові слова: цукровий діабет 2 типу; когнітивні порушення; діабетична стопа.

\section{ВСТУП}

Цукровий діабет (ЦД) є однією 3 найпоширеніших та найбільш ускладнених ендокринних патологій. У його виникненні на даний час роль психологічного параметра (стресу) є доведеною [1].

Поряд із відомими явищами, такими, як астенія, нервовова анорексія, дисторорія в структурі психічних порушень при цукровому діабеті останнім часом усе частіше стали відзначатися депресії та тривожні розлади різного ступеня вираження. Проведені дослідження показали, що особливістю для пацієнтів із цукровим діабетом стала наявність у клінічній картині іпохондричної фріксації на власних хворобливих переживаннях [2].
Diabetic foot and peculiarities of psychoemotional and cognitive disorders in patients with type 2 diabetes

L. V. Naumova, L. P. Mazur, V. M. Kulchinska

I. Horbachevsky Ternopil National Medical University

e-mail: mazur@tdmu.edu.ua

Summary. Diabetes mellitus is one of the most common and complicated endocrine pathologies. The role of psychological parameter (stress) in the occurrence of diabetes is currently proven.

The aim of the study - to identify psycho-emotional and cognitive disorders in patients with type 2 diabetes mellitus complicated by diabetic foot.

Materials and Methods. We examined 59 patients with type 2 diabetes, aged 45-70 years, with a disease duration of 4-22 years. The cognitive sphere was examined using the Mini Mental State Examination scale.

Results. The paper presents the results of the analysis of psychoemotional and cognitive disorders in patients with type 2 diabetes mellitus complicated by diabetic foot.

Conclusions. The authors note a direct relationship between the clinical form of diabetic foot and the degree of expression of cognitive impairment.

Key words: type 2 diabetes; cognitive impairment; diabetic foot.

У формуванні психічних розладів важливу роль відіграє тип цукрового діабету, його тривалість та ступінь компенсації. Початок хвороби в дитячому і підлітковому віці та тривалий (більше 8-9 років) перебіг захворювання створюють усі передумови для патологічного розвитку особистості хворих [3].

Пацієнти 3 цукровим діабетом - хронічно хворі люди, які здебільшого можуть гостро реагувати на своє захворювання і лікування. Подібні реакції зумовлені усвідомленням хронічного характеру хвороби з тривалими, гострими, прогресуючими ускладненнями та необхідністю постійного лікування [4].

Встановлення діагнозу цукрового діабету є шокуючим для більшості пацієнтів та їхніх рідних. Як 
наслідок, можуть виникати порушення психоемоційної сорери, що проявляється у вигляді розладів самооцінки, пригнічення, розпачу та депресії [5].

31986 р. використовується термін «діабетична особистість». Їй властиві емоційна нестійкість, невротичні реакції, байдужність, тривожність, лабільність настрою. Крім первинних розладів фрункції нервової системи, при цукровому діабеті мають значення соціально-психологічні фрактори (зниження працездатності, щоденні ін'єкції, статева диссрункція), особливості характеру індивідуума (тривожно-недовірливі риси в поєднанні 3 прямолінійністю, ригідністю психіки), несприятливі зовнішні впливи у формі перенапруження й психічних потрясінь, вплив тривалого медикаментозного лікування [6].

Депресивний психоз із тривогою або без неї найпоширеніший розлад у хворих на цукровий діабет. Багато вчених звертає увагу на наявність в осіб із цукровим діабетом депресій. Безліч авторів згадує про те, що вони спостерігають депресивні стани переважно в дебюті захворювання [7].

У літературі можна зустріти окремі описи депресії у хворих на цукровий діабет, що виникають при тяжкому перебігу ендокринного захворювання, що супроводжується частими комами.

Метою дослідження було виявити психоемоційні та когнітивні порушення у пацієнтів із цукровим діабетом 2 типу, ускладненого діабетичною стопою.

\section{МАТЕРІАЛИ І МЕТОДИ}

Ми обстежили 59 пацієнтів із ЦД 2 типу віком 45-70 років із тривалістю захворювання 4-22 роки. Когнітивну сфреру було обстежено за допомогою шкали Mini Mental State Examination.

\section{РЕЗУЛЬТАТИ Й ОБГОВОРЕННЯ}

У 59 пацієнтів із ЦД 2 типу за допомогою шкали Mini Mental State Examination було обстежено когнітивну сореру. Серед обтежених було 32 жінки $(54,24 \%)$ та 27 чоловіків (45,76 \%). Аналізуючи отримані результати, було виявлено порушеня когнітивних фрункцій у 10 осіб (16,9\%). У 43 пацієнтів (72,9 \%) виявили когнітивні порушення, та у 6 хво- рих (10,2 \%) була наявна деменція помірного ступеня вираження. Середній бал за шкалою MMSE у

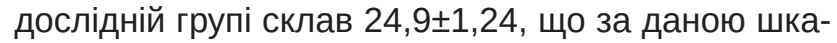
лою відповідає когнітивним порушенням (КП).

Всіх пацієнтів, які страждали від цукрового діабету в поєднанні з діабетичною стопою за віковою категорією та гендерними особливостями, поділи на 2 підгрупи: 1 підгрупа - 25 пацієнтів віком 45-59 років, 2 підгрупа - 34 хворих віком 60 років і старші.

Ми встановили, що в 1 підгрупі когнітивні порушення зустрічались відносно частіше серед жінок, що склало 57,1 \%, в той час як серед чоловіків КП діагностували в 45,5 \% у відповідній віковій підгрупі $(p<0,05)$.

Якщо ж аналізувати 2-гу підгрупу пацієнтів із ЦД 2 типу в поєднанні з діабетичною стопою, було помічено, що частота когнітивних порушень була більш вираженою у чоловіків і складала 83,3 \%, причому в 61,1 \% були наявні помірні когнітивні порушення, а у 22,2 \% - виявлено деменцію легкого ступеня. Отже, виходячи з вищевказаних даних, можна говорити про те, що в 1 підгрупі хворих віком від 45 до 59 років КП було виявлено у 52 \% , а у 2 пацієнтів із ЦД 2 типу у віковому діапазоні 60 років і старші КП були у 76,5 \% від загальної кількості обстежуваних в даній підгрупі, при чому у 23 \% з них було діагностовано деменцію легкого ступеня вираження, за допомогою шкали MMSE.

Порівнюючи дві вікові категорії та оцінюючи результати дослідження, можна говорити про те, що КП частіше зустрічаються у більш зрілому віці, а також більш вираженими КП були в чоловіків у віковій категорії 60 і старші, ніж у жінок $(p<0,05)$ (табл. 1).

Необхідно відзначити, що у хворих на ЦД 2 типу в поєднанні з діабетичною стопою тривалість захворювання впливала на прояви когнітивних порушень.

Залежно від тривалості захворювання на цукровий діабет та гендерної належності ми поділили групу пацієнтів із ЦД 2 типу на 2 підгрупи. До 1 підгрупи з тривалістю захворювання до 10 років увійшло 22 хворих, серед яких кількість жінок складала 12 осіб (52,4 \%) та 10 чоловіків (47,6 \%).

Тривалість захворювання ЦД 2 типу в 2 підгрупі становила від 11 років. Таких хворих було обсте-

Таблиця 1. Частота когнітивних порушень у хворих на ЦД 2 типу згідно з віковою категорією та гендерними особливостями

\begin{tabular}{l|c|c|c|c}
\hline \multirow{2}{*}{$\begin{array}{l}\text { Вік, загальна кількість } \\
\text { хворих }\end{array}$} & Кількість хворих, стать & кемає порушень & $\begin{array}{c}\text { когнітивні пору- } \\
\text { шення }\end{array}$ & $\begin{array}{c}\text { деменція легкого } \\
\text { ступеня }\end{array}$ \\
\cline { 3 - 5 } & & $1(9,1 \%)$ & $10(90,9 \%)$ & - \\
\hline $\begin{array}{l}45-59 \text { років, 25 паці- } \\
\text { єнтів }\end{array}$ & 11 чоловіків (44\%) & $2(14,3 \%)$ & $12(85,7 \%)$ & - \\
\cline { 2 - 5 } $\begin{array}{l}60 \text { років і старші, } \\
34 \text { пацієнти }\end{array}$ & 14 жінок (56\%) & $1(6,3 \%)$ & $13(81,3 \%)$ & $2(12,4 \%)$ \\
\cline { 2 - 5 } & 18 жінок (47,1\%) & $6(33,3 \%)$ & $8(44,4 \%)$ & $4(22,3 \%)$ \\
\hline
\end{tabular}

ISSN 2706-6282(print)

ISSN 2706-6290(online) 
жено 38, з яких кількість чоловіків була 17 (44,7 \%) і відповідно кількість жінок складала 21 особа (55,3 \%) (табл. 2).

Аналізуючи дані когнітивної сорери пацієнтів із ЦД 2 типу залежно від статі та тривалості захворювання, когнітивні порушення були наявні приблизно в однаковій відсотковій кількості як у чоловіків, так і у жінок, що склало $36,4 \pm 0,98$ ( $<<0,05)$ від загальної кількості пацієнтів у дослідній підгрупі 3 тривалістю захворювання до 10 років.

Вивчаючи результати 2 підгрупи, можна говорити про те, що ризик розвитку КП у пацієнтів із ЦД 2 типу в поєднанні з діабетичною стопою підвищується пропорційно зі збільшенням тривалості захворювання.
Залежно від наявної клінічної фрорми діабетичної стопи, усіх пацієнтів із ЦД 2 типу було поділено на 3 підгрупи. До 1 підгрупи 3 нейропатично-інфрікованою фрормою діабетичної стопи увійшло 20 пацієнтів (33,9 \%), 2 підгрупу склали пацієнти з ішемічно-гангренозною формою - 24 пацієнти $(40,7$ \%) і до 3 підгрупи зі змішаною фрормою було віднесено 15 осіб (25,4%) (табл. 3).

Проаналізувавши наявність КП у пацієнтів із ЦД 2 типу залежно від клінічної фрорми діабетичної стопи, було виявлено, що від когнітивної диссрункції у 1 підгрупі страждає 40 \%, у 2 підгрупі хворих 3 КП було 75 \%, а найбільш виражені КП спостерігалися у 3 підгрупі обстежуваних пацієнтів, що становило 86,7\%.

Таблиця 2. Когнітивні розлади у пацієнтів із ЦД 2 типу залежно від статі та тривалості захворювання

\begin{tabular}{|c|c|c|c|c|}
\hline \multirow{2}{*}{$\begin{array}{c}\text { Тривалість захворю- } \\
\text { вання, загальна кіль- } \\
\text { кість хворих }\end{array}$} & \multirow[b]{2}{*}{ Кількість хворих, стать } & \multicolumn{3}{|c|}{ Когнітивні порушення } \\
\hline & & $\begin{array}{c}\text { немає пору- } \\
\text { шень }\end{array}$ & $\begin{array}{c}\text { когнітивні пору- } \\
\text { шення }\end{array}$ & $\begin{array}{c}\text { деменція легкого } \\
\text { ступеня }\end{array}$ \\
\hline \multirow{2}{*}{$\begin{array}{l}\text { до } 10 \text { років, } \\
22(35,6 \%) \\
\end{array}$} & 10 чоловіків $(47,6 \%)$ & $6(60,0 \%)$ & $4(40,0 \%)$ & - \\
\hline & 11 жінок $(52,4$ \%) & $7(63,6 \%)$ & $4(36,3 \%)$ & - \\
\hline \multirow{2}{*}{$\begin{array}{l}\text { від } 11 \text { років, } \\
38(64,4 \%)\end{array}$} & 17 чоловіків $(44,7$ \%) & $4(23,5 \%)$ & $13(76,5 \%)$ & -- \\
\hline & 21 жінка (55,3 \%) & $2(9,5 \%)$ & $15(71,4 \%)$ & $4(19,1 \%)$ \\
\hline
\end{tabular}

Таблиця 3. Когнітивні порушення у хворих на Цд 2 типу залежно від клінічної фрорми діабетичної стопи

\begin{tabular}{|c|c|c|c|}
\hline $\begin{array}{c}\text { Клінічна стадія діабе- } \\
\text { тичної стопи }\end{array}$ & $\begin{array}{c}\text { Кількість хворих у } \\
\text { підгрупі }\end{array}$ & Кількість хворих без КП & Кількість хворих із КП \\
\hline 1 & $20(33,9 \%)$ & $12(60 \%)$ & $8(40 \%)$ \\
\hline 2 & $24(40,7 \%)$ & $6(25 \%)$ & $18(75 \%)$ \\
\hline 3 & $15(25,4 \%)$ & $2(13,3 \%)$ & $13(86,7 \%)$ \\
\hline
\end{tabular}

\section{ВИСНОВКИ}

1. Найвищий показник когнітивних порушень спостерігався у групі пацієнтів, які страждали від цукрового діабету в поєднанні зі змішаною фрормою діабетичної стопи, і становив 86,7 \%.

\section{СПИСОК ЛІТЕРАТУРИ}

1. Мокрій В. Я. Особливості формування окисноє го стресу у хворих на цукровий діабет 2-го типу залежно від тривалості захворювання та статі / В. Я. Мокрій, С. В. Зябліцев, М. В. Кришталь // Міжнародний ендокринологічний журнал. - 2016. - № 5. - С. 67-71.

2. Радченко О. М. Особливості перебігу цукрового діабету при різних типах загальних неспецифічних адаптаційних реакцій / О. М. Радченко, О. Я. Королюк, М. В. Сироїд // Галицький лікарський вісник. - 2003. - Т. 10, № 3. - С. 68-71.

3. Мокрий В. Я. Порушення системи перекисного окиснення ліпідів при цукровому діабеті 2-го типу : огляд літератури / В. Я. Мокрий, С. В. Зябліцев, Р. М. Борис // Міжнародний ендокринологічний журнал. - 2015. - № 7. - C. 41-44.

4. Павловський М. П. Вплив олії амаранту, насиченої синглетним киснем, на характер загальних адаптацій-
2. Ризик розвитку КП пропорційно підвищувався зі збільшенням тривалості захворювання.

3. Когнітивні порушення частіше зустрічалися у віковій категорії 60 років та старші, причому більш серйозні прояви спостеріаглися у чоловіків, ніж у жінок.

них реакцій у хворих із синдромом діабетичної стопи / М. П. Павловський, В. С. Заремба, Ю. А. Котик // Фітотерапія. - 2007. - № 3. - С. 3-9.

5. Жердьова Н. М. Взаємозв'язок між перифреричною діабетичною нейропатією та когнітивними порушеннями у пацієнтів на цукровий діабет 2 типу зрілого віку / Н. М. Жердьова, Б. М. Маньковський // Зб. наук. пр. співробітників НМАПО ім. П. Л. Шупика. - 2017. - Вип. 27. - C. 245-252.

6. The reaction of the neuroendocrine hypothalamus on intermittent hypoxia in rats with streptozotocine-induced diabetes / Yu. M. Kolesnik, E. V. Kadzharyan, A. V. Abramov, O. V. Melnikova // Клінічна фрармація. - 2013. - 17, № 4. - C. 41-44.

7. Мельник В. С. Взаємозв'язок між стресовою гіперглікемією та віддаленими наслідками гострого ішемічного інсульту / В. С. Мельник // Український медичний часопис. - 2006. - № 1. - С. 100-103. 


\section{REFERENCES}

1. Mokriy VYa, Ziabitsev SV, Kryshtal MV. [Features of the formation of oxidative stress in patients with type 2 diabetes depending on the duration of the disease and sex]. Mizhnar endokr zhurn. 2016;10(3): 67-71. Ukrainian.

2. Radchenko OM, Koroliuk OYa, Syroid MV. [Features of the course of diabetes mellitus in different types of general nonspecific adaptive reactions]. Hal likar visn. 2003;7:6871. Ukrainian.

3. Mokriy VYa, Ziabitsev SV, Borys RM. [Disorders of the lipid peroxidation system in type 2 diabetes mellitus (literature review)]. Mizhnar endokr zhurn. 2015;7: 41-4. Ukrainian.

4. Pavlovskiy MP, Zaremba VS, Kotyk YuA. [Influence of amaranth oil saturated with singlet oxygen on the nature of general adaptive reactions in patients with diabetic foot syndrome]. Fitoter. 2007;3: 3-9. Ukrainian.

5. Zherdiova NM, Mankovskiy BM. [Relationship between peripheral diabetic neuropathy and cognitive impairment in patients with type 2 diabetes mellitus in adulthood]. $\mathrm{Zb}$ nauk $\mathrm{pr}$ spivrob NMAPO im. P. L. Shupyka. 2017;27: 245-52. Ukrainian.

6. Kolesnik YuM, Kadzharyan EV, Abramov AV, Melnikova OV. The reaction of the neuroendocrine hypothalamus on intermittent hypoxia in rats with streptozotocine-induced diabetes. Klin farmac. 2013;17(4): 41-4.

7. Melnyk VS. [Relationship between stress hyperglycemia and long-term effects of acute ischemic stroke]. Ukr med chasopys. 2006;1: 100-3. Ukrainian. 